University of Wollongong

Research Online

Faculty of Business - Accounting \& Finance

Working Papers

Faculty of Business and Law

1993

\title{
Relative Profitability of Multinational Enterprises in a Developing Host Country: The Sri Lankan Experience
}

H. Wijewardena

University of Wollongong, hemawij@uow.edu.au

Follow this and additional works at: https://ro.uow.edu.au/accfinwp

Part of the International Business Commons

\section{Recommended Citation}

Wijewardena, H., Relative Profitability of Multinational Enterprises in a Developing Host Country: The Sri Lankan Experience, School of Accounting \& Finance, University of Wollongong, Working Paper 8, 1993.

https://ro.uow.edu.au/accfinwp/96

Research Online is the open access institutional repository for the University of Wollongong. For further information contact the UOW Library: research-pubs@uow.edu.au 


\section{DEPARTMENT OF ACCOUNTANCY}

\section{RELATIVE PROFITABILITY OF MULTINATIONAL ENTERPRISES IN A DEVELOPING HOST COUNTRY: THE SRI LANKAN EXPERIENCE}

by

Hema Wijewardena

University Of Wollongong

1993 Working Paper Series No. 8 


\title{
RELATIVE PROFITABULITY OF MULTINATIONAL ENTERPRISES IN A DEVELOPING HOST COUNTRY: THE SRI LANKAN EXPERIENCE
}

\author{
Hema Wijewardena \\ Department of Accountancy \\ University of Wollongong \\ Australia
}

\begin{abstract}
Multinational enterprises (MNEs) have played a vital role in the economies of developing countries. However, empirical studies on some crucial aspects of MNE involvement in these economies appear to be inadequate. One such aspect is the profitability of MNEs vis a vis indigenous enterprises. Therefore, covering a wider spectrum of individual country situations is needed in order to broaden our understanding of this aspect of MNE operations. This paper attempts to shed some light on this aspect through an analysis of balance sheet data of a sample of MNE affiliates operating in the manufacturing sector of Sri Lanka.

The empirical analysis of this study does not support the generally held view that MNEs are more profitable than their local counterparts. It reveals that profitability is not influenced simply by the origin of control or multinationality of investment when other factors such as the nature of industry and the age of firms are taken into account.
\end{abstract}




\section{RELATIVE PROFITABILITY OF MULTINATIONAL ENTERPRISES}

IN A DEVELOPING HOST COUNTRY: THE SRI LANKAN EXPERIENCE

\section{Introduction}

One of the striking developments in the economic activities of developing countries (DCs) from about the turn of this century has been the growing importance of the participation of multinational enterprises (MNEs) ${ }^{1}$. Originally, they were concentrated largely in the primary sector. ${ }^{2}$ The rapid industrial development taken place after World War II brought about an unprecedented expansion of MNE activity and the most rapidly growing sector of this activity in DCs during this period was manufacturing. Many DCs followed import substitution policies in the 1950s and 1960s and often a major beneficiary of these policies was the multinational enterprise. In the late 1960s and 1970s a number of developing countries adopted more export-oriented industrialisation strategies, the manifestation of which was the mushrooming of export processing zones around the world (Jenkins, 1987, p.7). Enticing MNE participation in export production was again a prime objective of such a strategy. Consequently, by 1985 about one fourth of overseas investment by MNEs was concentrated in developing countries (UNCTC, 1988, p.25).

There is a sizeable body of literature on MNE activity in developing countries. Empirical evidence on some crucial aspects of MNE activity is, however, still sparse. One such aspect is the profitability of MNEs vis a vis indigenous enterprises. There is certainly a need for more empirical investigations covering a wider spectrum of individual country situations in order to broaden our understanding of this aspect of MNE operations. The present study is an attempt in this direction.

\footnotetext{
${ }^{1}$ In line with usual practice in this area of study the multinational enterprise (MNE) is defined here as an enterprise that owns or controls income-generating assets in one or more countries other than the one in which it is based.

${ }^{2}$ By the outbreak of World War I over 60 per cent of all direct foreign investment was located in developing countries and 55 per cent of them were in the primary sector (Dunning, 1983, p.89)
} 


\section{Review of Previous Work}

A generally held view regarding the operations of MNEs in both developed and developing host countries is that they are more profitable than their local counterparts. As far as this author is aware, the only comprehensive empirical investigation to verify this view on developing countries is an UNCTAD study by Lall and Streeten (1977) which examines the operation of 109 transnational corporations (TNCs) ${ }^{3}$ in India and Colombia for 1969-9. This study, however, comes up with conflicting results in respect of relative profitability of firms. In the Indian sample, TNCs as a whole are more profitable than non-TNCs whereas the Colombian sample shows exactly the opposite in terms of every measure employed. Further, the authors report that when the data of the above two countries are combined with those of four other developing countries (Jamaica, Kenya, Iran and Malaysia) the overall result fails to indicate any significant difference of profitability between TNCs and non-TNCs in developing countries. Based on a study of a sample of 33 pairs of industrial firms in Costa Rica in 1971, Willmore (1976, p.509) also reports that there is no significant difference between foreign and local firms in Central America.

In a more recent ESCAP study on the operations of transnational trading corporations (TTCs) in Sri Lanka, Athukorala and Lakshman (1985, p.344) found that TTCs stand out as being more profitable compared with their local counterparts. The test of profitability in their study is based on trading firms and no attempt has been made to measure the performance of MNE affiliates operating in the manufacturing sector.

The evidence available from industrial countries is also mixed. Safarian (1969, ch.6) reports that there does not appear to be a significant overall difference between the two sets of firms in Canadian manufacturing, but Brash (1966, ch.10) and Dunning $(1969$, p.136) found that US-owned manufacturing plants showed a substantially higher

\footnotetext{
${ }^{3}$ The term, 'transnational' is used in UN publications as a preferred substitute to 'multinational'.
} 
rate of return than domestically-owned plants in Australia and the United Kingdom respectively.

\section{Multinational Enterprise Involvement in Sri Lankan Manufacturing}

As in many other developing countries, import control was the major factor which triggered the entry of direct foreign investment into Sri Lankan manufacturing (Athukorala and Jayasuriya, 1987, p.411). In the early 1960s in response to a severe balance of payments crisis, Sri Lanka moved rapidly to a regime of stringent import and exchange restrictions, placing heavy emphasis on an import substitution strategy. When their market shares were threatened by import controls many foreign firms set up affiliates within Sri Lanka to undertake the domestic production and/or assembly of product lines which had hitherto been supplied from their overseas production centres. During the 1960 s, facilitated by a favourable government policy stance, MNEs expanded their role in the domestic manufacturing sector. By the end of the decade, there were 51 MNE affiliates in operation, and they accounted for about 28 per cent (38 per cent if the public sector is excluded) of total manufacturing output (Fernando, 1971, p.84).

As evident from Table 1, the period from 1970 to 1977 witnessed a notable reduction in the tempo of direct foreign capital participation in the economy. The commitment to socialism by the government in power during this period led to the introduction of a new industrialisation policy aimed at expanding the role of the public sector by setting up new public corporations and nationalising some of the privately owned enterprises (Betancourt, 1981, p.33). This policy apparently had considerable adverse effect on the expansion of MNE activity in the economy. The change in political leadership in 1977 brought about a liberalised economic environment with a marked shift in the industrialisation policy. The promotion of foreign capital participation in manufacturing, notably in export-oriented industries, was a pivotal element of the development strategy of the new "right-of-centre" government (Lal and Rajapatirana, 1988, p.45). Setting up of an export processing zone (the Katunayaka Investment 
Promotion Zone) in 1978 was one of the major steps taken in this direction. Despite the political uncertainty that resulted from the worsening of the country's ethnic conflict since 1983 the new policy orientation proved to be very attractive to foreign investors over the post-liberalisation period (Table 1).

\section{Table 1}

MNEs in Sri Lankan Manufacturing

\begin{tabular}{cc}
$\begin{array}{l}\text { Period of } \\
\text { establishment }\end{array}$ & $\begin{array}{c}\text { Total number } \\
\text { of affiliates }\end{array}$ \\
\hline Prior to 1950 & 3 \\
$1950-1959$ & 80 \\
$1960-1969$ & 20 \\
$1970-1977$ & 222 \\
$1978-1985^{a}$ & 293 \\
\hline Total & 29 \\
\hline
\end{tabular}

a Figures in this period include firms in trial production and under construction. Source: Athukorala and Jayasuriya (1988), Table 1

\section{Data and Methodology}

Against this background, we proceed in this section to examine the profitability of MNE affiliates vis a vis local firms operating in the manufacturing sector of Sri Lanka. This is done through a comparative analysis of their balance sheets and profit and loss statements. The sample firms used for this analysis consist of $10 \mathrm{MNE}$ affiliates and 10 local firms ${ }^{4}$ operating in the manufacturing sector. All these firms are public limited companies listed in the Colombo Stock Exchange. To avoid distortion from possible random variations, the analysis is based on average figures for the three years from 1987 to 1989.

The data for the analysis comes from the Sri Lanka Equity Guide 1991. At the outset, a few words of caution are warranted regarding the limitations of published accounts. Published company accounts data are not completely reliable indicators of the

\footnotetext{
4 The number of sample firms was limited to 20 due to the lack of comparable manufacturing firms.
} 
'performance' of firms, and much less so when some of the 'values' are determined directly by the firms concerned. Profit figures particularly in the case of multinational companies, may be liable to various manipulations through practices such as transfer pricing (Robbins and Stobaugh, 1974, p.91). Some items, such as the amount of depreciation and the value of inventories are subject to arbitrary valuation within a fairly wide range. Moreover, particularly in respect of fixed assets, accounting figures based on the historical cost concept may not represent realistic values in a period of inflation. There are also the basic conceptual problems of defining items such as 'capital employed' and 'current liabilities'. Finally, there is the difficulty of comparing and interpreting balance sheet data which represent the financial position at one particular point in time of the lives of firms having different ages and facing different market conditions. There is little one can do to resolve these problems which pervade all studies of this type. In any case, economic policies relating to the business sector and also the existing literature on the performance of MNEs are largely based on the available published data. As such, an analysis based on published accounts is considered relevant and useful particularly in a developing country context.

The principal measure of profitability used in this study is the return on investment (ROI) which is shown as net income before taxes divided by capital employed. 'Capital employed' may be defined in a number of ways and the two most widely accepted definitions are 'gross capital employed' and 'net capital employed'. Gross capital employed usually represents total assets while net capital employed comprises total assets less current liabilities. 'Net capital employed' is used in this study because it represents investment more realistically in practical sense. However, it is important to note that 'net capital employed' used here is slightly different from the usual definition. The definition adopted here is 'total assets less current liabilities other than short-term bank borrowings. The argument here is that short-term bank borrowings are rolled over continuously from year to year and, therefore, should in reality be treated as long-term loans (Lall and Streeten, p.106). 
'Net profit before taxes' is used in the numerator for several reasons. First, it would improve comparability among firms by avoiding possible distortions that could be caused by company tax deductions particularly because some companies enjoy different types of tax holidays and exemptions. Second, taxes are primarily charged on profits earned and are generally uncontrollable by management. Third, there is some evidence that parents of MNEs generally use before-tax rates of return in evaluating affiliates. ${ }^{5}$ For these reasons, the analysis of this study focuses mainly on the before-tax rate of return.

Ideally, from an economic standpoint, the numerator of ROI should also include interest paid by firms in order to find the rate of return on net total capital employed including those based on borrowed funds (Wolf, 1975, p.18). Unfortunately, the necessary data is not available for such an adjustment.

In order to verify the validity of results of ROI by looking at profitability from alternative angles, we have also used four more measures based on net sales, net fixed assets and net worth as shown in Table 2. One of these additional measures (return on net worth) has been calculated taking profit on both before and after tax bases to highlight the impact of taxation on profitability.

\section{Results}

In terms of sales, MNEs in the sample appear to be over four times larger than local firms. The main reason for this exceptionally large difference is that Ceylon Tobacco which is one of the most well established MNE affiliates in Sri Lanka accounts for nearly 49 per cent of total sales in the sample. Even when this extreme case is excluded, the sales volume of MNEs, on average, still remains as larger than twice that of the local firms.

\footnotetext{
5 See page 143 of Money in the Multinational Enterprise by Sydney M. Robbins and Robert B. Stobaugh (New York: Basic Books, Inc., 1973).
} 
Table 2

Profit Performance of MNE Affiliates and Local Firms, 1987-89 (Percetages)

\begin{tabular}{|c|c|c|c|c|c|c|}
\hline Firm & $\begin{array}{l}\text { Years } \\
\text { in } \\
\text { Operation }\end{array}$ & \begin{tabular}{c}
$\mathrm{NPBT}^{\mathrm{a}}$ \\
\hdashline $\mathrm{CE}$
\end{tabular} & \begin{tabular}{c}
$\mathrm{NPBT}^{\mathrm{b}}$ \\
\hdashline $\mathrm{NS}$
\end{tabular} & $\begin{array}{c}\text { NPBT }^{\mathrm{c}} \\
\mathrm{NFA}\end{array}$ & $\frac{\mathrm{NPBT}^{\mathrm{d}}}{\mathrm{NW}}$ & $\frac{\text { NPAT }^{\mathrm{e}}}{\mathrm{NW}}$ \\
\hline MNE Affiliates (Avera & & 21.01 & 7.69 & 55.26 & 29.80 & 17.73 \\
\hline Acme Aluminium & 40 & 20.41 & 11.92 & 45.47 & 27.08 & 23.22 \\
\hline Bata Shoes & 39 & 23.80 & 10.46 & 42.86 & 30.07 & 16.14 \\
\hline Ceylon Match & 71 & 4.15 & 3.37 & 4.55 & 7.20 & 4.47 \\
\hline Celon Tobacco & 71 & 21.68 & 6.22 & 42.17 & 39.25 & 23.63 \\
\hline Chemical Industries & 25 & 32.16 & 6.75 & 178.47 & 49.79 & 27.13 \\
\hline Glaxo Ceylon & 33 & 23.80 & 7.78 & 58.48 & 30.93 & 15.76 \\
\hline Lankem Ceylon & 25 & 3.72 & 2.25 & 9.43 & 8.52 & 3.40 \\
\hline Nestle Lanka & 12 & 8.48 & 5.55 & 11.78 & 9.32 & 9.32 \\
\hline Reckitt \& Colman & 27 & 54.08 & 16.88 & 106.90 & 58.33 & 31.89 \\
\hline Singer Industries & 25 & 17.79 & 5.71 & 52.52 & 37.48 & 22.32 \\
\hline Local Firms (Average) & & 21.35 & 11.90 & 55.27 & $\mathbf{3 1 . 8 7}$ & 24.08 \\
\hline Associated Cables & 27 & 14.78 & 7.48 & 37.58 & 44.62 & 30.14 \\
\hline Associated Electricals & 27 & 33.29 & 13.71 & 117.90 & 37.76 & 19.24 \\
\hline Chemanex & 15 & 10.29 & 4.61 & 44.44 & 18.18 & 10.97 \\
\hline Dipped Products & 13 & 28.11 & 30.49 & 79.21 & 41.13 & 41.13 \\
\hline Haycarb & 16 & 31.32 & 29.45 & 109.46 & 41.78 & 37.32 \\
\hline Industrial Asphalts & 25 & 9.39 & 3.75 & 10.63 & 11.72 & 10.37 \\
\hline Keels Food Products & 7 & 26.20 & 9.87 & 34.92 & 26.55 & 24.23 \\
\hline Kelani Cables & 20 & 28.99 & 9.26 & 56.12 & 46.04 & 29.67 \\
\hline Pure Beverages & 34 & 3.69 & 2.01 & 4.09 & 9.23 & 6.30 \\
\hline Richard Peiris & 66 & 27.41 & 8.41 & 58.30 & 41.71 & 31.46 \\
\hline
\end{tabular}

Source: Compiled using data from Sri Lanka Equity Guide, February 1991

Notes: a Return on investment $=$ Net profit before tax/capital employed $b_{\text {Return on sales }}=$ Net profit before tax/net sales

${ }^{c}$ Return on fixed assets $=$ Net profit before tax/net fixed assets

d Return (before tax) on net worth $=$ Net profit before tax/net worth

e Return (after tax) on net worth $=$ Net profit after tax/net worth 
When the relative sizes of firms are measured in terms of capital employed MNEs are seen, on average, to be about two and a half times larger than local firms. This size difference in the Sri Lankan sample is quite consistent with the one reported by Lall and Streeten in the Indian sample. Also, it is reported in the literature that there is much stronger confirmation of this pattern in more developed economies. For example, Parry (1974) found, on comparing 223 TNC subsidiaries to 757 non-TNC subsidiaries in the Australian manufacturing sector in 1971 that, on average, the former were 3.7 times larger than the latter.

It is seen from Table 2 that MNEs as a whole are not more profitable than local firms in terms of ROI as well as all the other measures employed. As anticipated, the results of ROI are reinforced by those of the additional four measures. The average rate of return on investment for MNEs was 21.01 per cent compared to 21.35 per cent for local firms. Their profit performance seems significantly weaker when viewed as a return on net sales which is only 7.69 per cent for MNEs whereas local firms have achieved a rate of 11.9 per cent. Similarly, their performance seems much lower and disadvantageous particularly for equity owners when measured as an after-tax rate of return on net worth. This ratio is only 17.73 per cent for MNEs whereas it is 24.08 per cent for their local counterparts. However, before-tax rate of return on net worth is 29.8 per cent and 31.87 per cent respectively, indicating a very small difference. The reason for this appears to be that taxes paid by MNEs have been considerably higher as a percentage of net profit (35\%) than those paid by local firms (19\%). As pointed out earlier, such differences of taxation are obvious given the tax holidays and exemptions enjoyed by some firms.

The above situation on the profitability of manufacturing MNEs as a whole is quite unexpected since the trading MNEs in Sri Lanka have been reported to be significantly more profitable than their local counterparts (Athukorala and Lakshman, 1985, p.344). Furthermore, the situation demonstrated by our data is exactly the opposite of the experience reported by Lall and Streeten on manufacturing MNEs in India where 
the rate of return on investment (NPBT/CE) is 23.3 per cent for MNEs and 13.9 per cent for non-MNEs. However, our finding is compatible with the experience in Colombia where the same ratio is 23.5 per cent for MNEs and 25.7 per cent for non-MNEs (Lall and Streeten, 1977, p.121).

Within each group, however, there are vast differences in profitability among individual firms. Among the MNE group, for example, Reckitt and Colman, and Chemical Industries showed rates of return on investment as high as 54.08 per cent and 32.16 per cent respectively while those of Lankem and Ceylon Match were as low as 3.72 per cent and 4.15 cent respectively. A similar pattern is seen in the local group as well. For example, Haycarb and Dipped Products showed high profitability being well above the group averages by all measures employed while Pure Beverages was at the other extreme. This suggests that the "product specific" factors are importatnt in explaining relative profitability of individual firms. In order to shed further light on this aspect we calculated ROI for the sample firms according to industry (Table 3). It should be noted that the classification of industries in this table has been limited to only four groups because of the small number of firms in the sample.

Table 3

Return on Investment of Sample Firms, by Industry, 1987-89a

\begin{tabular}{|c|c|c|c|c|}
\hline \multirow{2}{*}{ Industry } & \multirow{2}{*}{$\begin{array}{l}\text { Pairs } \\
\text { of } \\
\text { Firms }\end{array}$} & \multicolumn{3}{|c|}{ Rate of Return ${ }^{b}$} \\
\hline & & MNEs & Local Firms & All Firms \\
\hline Food, beverages \& tobacco & 2 & 15.08 & 14.95 & 15.02 \\
\hline Chemical and rubber products & 4 & 28.44 & 18.80 & 23.62 \\
\hline Fabricated metal products & 2 & 19.10 & 21.89 & 20.50 \\
\hline Other & 2 & 13.98 & 32.31 & 23.15 \\
\hline All Industries & 10 & 21.01 & 21.35 & 21.18 \\
\hline
\end{tabular}

Source: Table 2

Notes: a Annual averages

b Net profit before taxes/capital employed (percentage)

Table 3 shows that the profitability of sample firms varies greatly between industries within each group of firms. For example, the rate of return within the MNE 
group varies from 15.08 per cent in food, beverages and tobacco to 28.44 per cent in chemical and rubber products. The same ratio shows a smaller variation (14.95\%$18.8 \%$ ) within local firms between these two categories of industries. This type of variations in profitability might be partly due to the difference in the nature of products handled which are subject to different production and market situations. In the above industries, MNEs seem to have achieved a higher level of profitability than that of local firms. Nonetheless, in the 'other' category which comprises a mix of industries such as footware, electrical appliances and safety matches, MNEs have been considerably less profitable than local firms.

Two other factors often considered to be correlated with profitability are the age and size of firms. ${ }^{6}$ To examine the impact of age, the sample firms were divided into two age groups: upto 25 years $^{7}$ and over 25 years. As shown in Table 4 , the profitability of sample firms varies dramatically between MNEs and local firms according to their age. Among the older firms, MNEs indicate a higher degree of profitability than local firms. Contrary to this, however, the younger group accounts for a much higher level of profitability for local firms. The reason for this situation is not clear from the available information. Moreover, the validity of this finding diminishes to some extent due to the smallness of the sample and the excessively high upper age limit of the younger group.

Table 4

Return on Investment of Sample Firms, by Age, 1987-89a

\begin{tabular}{lccc} 
& & \multicolumn{3}{c}{ Rate of Return } \\
Age of Firms & MNEs & Local Firms & All Firms \\
\hline Upto 25 years & 15,54 & 24.39 & 20.85 \\
Over 25 years & 24.65 & 19.79 & 22.71 \\
All groups & 21.01 & 21.35 & 21.18 \\
\hline
\end{tabular}

Source: Table 2

Notes: a Annual averages

b Net profit before taxes/capital employed (percentage)

c Consists of $4 \mathrm{MNE}$ affiliates and 6 local firms.

${ }^{6}$ See Leftwich (1974) for some evidence on the impact of both these factors on profitability.

${ }^{7}$ Since only one firm among MNEs has been in operation for a period lower than 25 years (see Table 2), it is not possible to make the upper age limit shorter than this. 
It is not possible to make a valid assessment of the impact of firm size on profitability because the smallness of the sample precludes any meaningful classification of firms into size classes. Nevertheless, it is noteworthy that a considerable number of smaller firms such as Reckitt and Colman, Kelani Cables, and Keels Food Products with relatively lower capital investments have recorded markedly higher profit rates than most of the larger ones. Some of the other factors that have caused profitability differences between MNE affiliates and local firms in our sample may include differences in the policies of individual firms with regard to depreciation and valuation of assets and their overall efficiencies in managing resources. However, any conclusion on such factors cannot be made without detailed case studies on individual firms.

\section{Conclusion}

The empirical analysis of this study does not support the generally held view that MNEs are more profitable than their local counterparts. Profitability is not influenced simply by the origin of control or multinationality of investment when other factors such as the nature of industry and the age of firms are taken into account. This confirms the finding of Lall and Streeten (1977) for the Colombian manufacturing firms. 


\section{References}

Athukorala, Premachandra and S.K. Jayasuriya (1988),'Parentage and Factor Proportions: A Comparative Study of Third-World Multinationals in Sri Lankan Manufacturing', Oxford Bulletin of Economics and Statistics, Vol. 20, pp.70-94

Athukorala, Premachandra and W.D. Lakshman (1985), 'Activities of Transnational Trading Corporations in the Sri Lankan Economy', Transnational Trading Corporations in Selected Asian and Pacific Countries, ESCAP, Bangkok

Betancourt, R.R. (1981), "The Utilisation of Industrial Capital and Employment Promotion in Developing Countries: Multiple shifting as an emergency employment scheme in Sri Lanka", Industrial Capacity and Employment, Geneva: ILO, pp.26-75

Brash, D.T. (1966), American Investment in Australian Industry, Canberra: Australian National University Press, Chapter 10

Dunning, J.H. (1969), The Role of American Investment in the British Economy, London: Politics and Economic Planning

Dunning, J.H. (1981), International Production and the Multinational Enterprise, London, George Allen \& Unwin

Dunning, J.H. (1983), 'Changes in the level and structure of international production: the last one hundred years', in M. Casson (ed.), The Growth of International Business, London, George Allen \& Unwin

Fernando, L.E.N. (1971), Some Aspects of Private Foreign Enterprises in Ceylon, PhD Thesis, University of Hull

Jenkins, R. (1987), Transnational Corporations and Uneven Development, London: Methuen \& Co Ltd.

Lal, D. and S. Rajapatirana (1988), Impediments to Trade Liberalisation in Sri Lanka, Thames Essay No. 53, London, Trade Policy Research Centre

Lall, S. and P. Streeten (1977), Foreign Investment, Transnationals and Developing Countries, London, Macmillan 
Leftwich, R.B. (1974), "US Multinational Companies: Profitability, Financial Leverage and Effective Tax Rates", Survey of Current Business, May, pp.27-36

Parry, T.G. (1974), 'Technology and Size of the Multinational Corporation Subsidiary: Evidence from the Australian Manufacturing Sector", Journal of Industrial Economics, December, pp. 125-34

Robbins, S.M. and R.B. Stobaugh (1974), Money in the Multinational Enterprise: A Study of Financial Policy, London, Longman

Safarin, A.E. (1969), The Performance of Foreign Owned Firms in Canada, Montreal: Private Planning Association

Sri Lanka Equity Guide, ((1991), February, Colombo: Mackinnon \& Keels Financial Services Ltd.

UNCTC (1988), Transnational Corporations in World Development: Trends and Prospects, New York, United Nations

Willmore, L. (1976) "Direct Foreign Investment in Central American Manufacturing", World Development, Vol.4 No.6, pp.499-517

Wolf, B.N. (1975), "Size and Profitability among US Manufacturing Firms: Multinational versus Domestic Firms", Journal of Economics and Business, Fall, pp.15-22 